\title{
The Roles of Ambient Pride Type on the Responses to Preference Inconsistent Information
}

\author{
선호 불일치 정보에 대한 반응에서 환경적 프라이드 유형의 역할* \\ Nak-Hwan Choi(최낙환) ${ }^{* *}$
}

Received: October 03, 2018. Revised: October 30, 2018. Accepted: November 10, 2018.

\section{Abstract}

Purpose - Present research aimed at identifying the effects of ambient pride type on judgement difference between existing preference and final preference formed after being exposed to the preference inconsistent information from others representing a conflict between consumer's own perspective and the others' perspective. And this study also explored the roles of empathic concerns and motive type in the ambient pride type's effects on the judgement difference.

Research design, data, and methodology - 2(information type: consistent versus inconsistent) $\times 2$ (pride type: hubristic versus authentic) between-subjects design was employed. Data for empirical analysis were from 252 undergraduate students who participated in questionnaire survey. To verify hypotheses, Anova and regression analysis were used.

Results - First, there was the judgement difference among the experimental groups. The difference was greater at the authentic pride group than at the hubristic pride group. And the difference was greater at the inconsistent information group than at the consistent information group. The interaction effect of pride type and information type was significant. Second, when consumers who had made their preference were exposed to the inconsistent information from other, those of the hubristic pride group showed more defense motive and less empathic concerns than those of the authentic pride group. And there were the mediation roles of the empathic concerns and the interaction roles of the motive type in the effects of pride type on the judgement difference. Third, the self validity did not affect the difference even that become increased by defense motive rather than accuracy motive.

Conclusions - This research could advance the information processing theory related to pride type by exploring the effects of the pride type on judgement difference between existing preference and final preference formed by the inconsistent information from others, and by identifying the mediation roles of the empathic concerns and the interaction roles of the motive type in the effects of the pride type. In view of the results from current study, marketers should make efforts of inducing defense motive and developing and communicating the consistent information to persuade consumers under hubristic pride who have the belief that attributes of their brand are better than those of the competitors' brand, and they also should conduct marketing acts by using the inconsistent information to persuade consumers under authentic pride who have the belief that attributes of the competitors' brand are better than those of their brand.

Keywords: Empathic Concerns, Judgement Difference, Motive Type, Preference Inconsistent Information, Pride Type.

JEL Classifications: C83, L81, M31, P46.

* This work was supported by the Ministry of Education of the Republic of Korea and the National Research Foundation of Korea (NRF-2017S1A5A2A02068474). This research was supported by "Research Base Construction Fund Support Program" funded by Chonbuk National University in 2018.

** Professor, Department of Business Administration, Chonbuk National University, Korea. Tel: +82-63-270-2998, E-mail: cnh@jbnu.ac.kr

\section{1. 서론}

소비자는 제품의 판단과 선택여부의 결정에서, 자신의 자아 를 준거기준으로 사용하는데(Rogers, Kuiper, \& Kirker, 1977; Weiss \& Johar, 2013), 소비자가 느끼는 프라이드는 성공의 요인으로 자아가 귀인 되어 느끼는 자아의식 감정이다. 그런데 오만성 프라이드(hubristic pride)는 자질(traits)적 자아에 초점 을 두고 느끼는 프라이드이고, 진정성 프라이드(authentic 
pride)는 노력(efforts)하는 자아에 초점을 두고 느끼는 프라이 드이다(Beer \& Keltner, 2004; Tracy \& Robins, 2004; Tracy \& Robins, 2007). 자질적 자아와 노력하는 자아는 서로 달라 서, 사전에 자질적 자아에 귀인으로 느끼는 오만성 프라이드와 노력하는 자아에 귀인으로 느끼는 진정성 프라이드는 소비자 의 정보처리에서 환경적 영향요소로 작용하여 서로 다른 영향 을 미칠 수 있다. 마케터에게 소비자의 정보처리 결과는 제품 이나 브랜드에 관한 메시지의 효과를 의미하고 또 충성도에 영향을 미칠 수 있어서, 일상의 생활에서 소비지가 목적을 성 취하여 느끼는 프라이드의 유형에 따른 정보처리과정의 이해 는 마케팅관리의 효율성에 기여할 수 있다. 따라서 사전에 느 끼는 환경적 프라이드의 유형을 구분하여 감정의 진화적 접근 관점(evolutionary approach)(Cosmides \& Tooby, 2000; Kenrick \& Shiota, 2008)에서 소비자의 동기, 정보처리, 그리고 판단과 의사결정 등의 행동을 탐색할 필요가 있다.

그런데 기존의 연구는, 프라이드의 유형을 구분하지 않고, 미래의 업적을 위한 프라이드의 동기유발효과(motivation) (Louro, Pieters, \& Zeelenberg, 2005), 탐닉적 선택에서 프라 이드의 긍정적 역할(Wilcox, Kramer, \& Sen, 2011), 자기효능 감(self-efficacy)과의 관련성(Passyn \& Sujan, 2012) 등을 연구 하였으며, Agrawal, Han, and Duhachek(2013)도 프라이드의 유형을 구분하지 않고 프라이드를 느끼는 소비자가 선호불일 치 정보에 의존하는 정도가 약하다고 주장하였다.

본 연구는 감정평가이론(appraisal tendency framework) (Lerner \& Keltner, 2000; Lerner, Han, \& Keltner, 2007)의 관 점에서 성공에 자질이 귀인 되어 느끼는 오만성 프라이드와 노력이 귀인 되어 느끼는 진정성 프라이드를 구분한다. 그리고 진화적 접근 관점에서 소비자가 자신의 선호에 불일치되는 타 인의 정보에 노출되었을 때에 사전에 오만성 프라이드를 느끼 는 소비자와 진정성 프라이드를 느끼는 소비자 간에 초기 판 단과 최종 판단의 차이가 다른 정도를 정보처리의 동기, 불일 치되는 타인의 정보에 대한 공감적 관심(empathic concerns) 그리고 자기 타당화(self validation)의 개념을 도입하여 연구한 다.

자기타당화 가설과 관련된 Petty, Briñol, and Tormala(2002) 의 실험에서 자신의 기존생각을 확신하는 소비자는 의심하는 소비자 보다 자신의 사고에 더 주의를 하고, 설득 메시지에 저 항하였다. 그들의 실험결과는 새로운 설득정보를 정확하게 처 리하려는 동기 보다 기존의 신념에 주의하고 기존의 지식구조 의 정신적 경계를 유지시키는 정신적 방어의 관점(Hart, 2014) 과 상통한다.

그리고 Dweck(2006)은 직무와 관련하여 수행지향성 (orientation toward performance)과 과업지향성(orientation toward task)을 구분하고, 직무수행가능성에 초점을 두는 수행 지향적인 사람은 실패를 유능하지 못한 자신의 불변적 능력부 족의 결과로 보고 차후의 유사한 과업에서도 성공을 확신하지 못하지만, 과업지향적인 사람은 능력은 경험하면서 학습된다고 생각하여, 실패경험이 차후에 유사한 과업에서 다른 행동을 하 게 하여 성공을 할 수 있다는 확신을 갖게 할 수 있음을 연구 했다. 과업에 필요한 구체적인 노력행동에 초점을 두는 소비자 는 기존의 신념을 방어하려는 동기 보다 과업수행에 필요한 것을 배우려는 학습목표를 갖고, 정보처리에서 정확성 동기를 더 갖는다. 즉 노력(능력)에 초점을 두는 소비자는 능력(노력) 에 초점을 두는 소비자 보다 정확성(방어) 동기를 가질 수 있 다.
자신만의 자질적 자아에 초점을 두고 오만성 프라이드를 느 끼는 소비자는 자질적 자아체계와 경계를 유지하려는 방어 동 기를 갖고, 타인의 새로운 불일치정보에 노출되었을 때 공감하 지 않고 자신의 기존 신념을 강화하는 자기타당화 수준이 높 아서 기존의 초기판단이 최종판단이 될 수 있다. 그런데 노력 하는 자아에 초점을 두고 진정성 프라이드를 느끼는 소비자는 정확하게 정보를 처리하려는 동기를 갖고, 타인의 새로운 불일 치정보에 노출되었을 때 자기타당화 수준이 낮아서, 기존의 초 기판단과 최종판단이 서로 다를 수 있다.

따라서 이 연구는, 첫째, 프라이드 유형을 오만성 프라이드 와 진정성 프라이드로 구분하여 타인의 불일치 정보에 대한 공감적 관심과 정보처리 동기의 차이를 탐색한다. 둘째, 기존 선호에 불일치되는 정보에 노출되었을 때에, 사전에 느끼는 환 경적 프라이드의 유형에 따라 초기판단과 최종판단 간의 차이 가 다른가를 식별한다. 셋째, 초기판단과 최종판단 간의 차이 에 대한 환경적 프라이드의 유형효과에서 공감적 관심의 매개 역할과 정보처리 동기의 유형의 상호작용역할을 탐색한다. 넷 째, 정보처리 동기의 초기판단과 최종판단 간의 차이 효과에서 자기타당화의 매개역할을 탐색한다. 다섯째, 연구의 결과를 바 탕으로 소비자가 사전에 느끼는 프라이드의 유형별로 필요한 설득 메시지의 접근방법을 관리적 시사점으로 제시한다.

\section{2. 이론적 배경과 가설의 설정}

\section{1. 오만성 프라이드와 진정성 프라이드}

지능 또는 자질 등의 보편적인 자아(global self)에서 자신의 우수성이 성공에 귀인 되면 오만성 프라이드를 느끼고, 자신이 행동한 자아의 구체적인 측면(specific self)이 성공에 귀인되면 진정성 프라이드를 느낀다(Tracy \& Robins, 2004, 2007, 2014). 보편적인 자아의 귀인에는 타인과 비교하여 내가 누구 인가의 객체(object)로서 자아와 내가 행위의 주인공인 주체 (subject)로서 자아가 모두 존재하고, 객체자아가 주체자아의 행위에 귀인 되는 평가에서 객체자아가 주체자아에 얽혀져 전 체자아(total self)를 형성한다. 업적을 성취한 내가 누구인가에 대한 평가에서, 초점이 자신의 행동에 있지 않고 보편자아에 있으면, 소비자는 자신의 자아 외에 다른 것을 생각하지 않는 다. 그런데 구체적인 귀인에서는 좋고 올바른 일을 해낸 것은 보편자아가 아니고 특정의 상황과 시각에서 구체적인 행동이 기 때문에 구체적인 자아가 귀인 되며, 특정 대상이나 사람과 상호작용한 자신의 행동이 초점을 받게 된다(Lewis, 2016). 따 라서 자아의식적인 프라이드 감정은 단일차원의 개념으로 접 근하기 보다 오만성 프라이드와 진정성 프라이드로 구분하여 접근할 필요가 있다(Tracy \& Robins, 2007).

\section{2. 기존 신념에 불일치하는 정보의 처리에 관한 기존의 연구}

신념은 표적의 의미를 어떤 판단기준의 관점에서 특정 위치 (position)에 명확하게 투영하는 행동으로 정의된다(McGuire, 1989). 그런데 신념과 불일치하는 위협정보에 노출된 소비자 의 정보처리에 관한 기존 연구는 그 위협정보에 대항하여 자 신의 신념이나 지식체계를 유지하는 정보처리를 한다는 주장 
과 정확성 목적이 상기되어 기존의 신념이나 지식체계의 유지 보다 정확하게 정보를 처리한다는 주장으로 양분된다. 기존의 신념을 유지하고 보상하는 정보처리(compensatory processes) 는 정신적 방어(psychological defense)의 관점에서 설명될 수 있는 정보처리이다(Hart, 2014). 보상적 정보처리는 기존 지식 구조의 정신적 경계(mental boundaries)를 유지시키는 정보처 리를 하여(Cutright, Bettman, \& Fitzsimons, 2013), 자신의 지 식체계의 질서와 구조의 붕괴를 막으려 하고(Kay, Whitson, Gaucher, \& Galinsky, 2009), 자신의 신념을 지켜서 기존의 선 호도를 강화시키는 방어적 정보처리이다(Cutright, 2012). 자신 의 기존 신념이나 지식을 위협하는 정보로부터 기존의 지식과 신념을 방어하고 보상적으로 정보를 처리하는 경우에, 초기 신 념이나 기존의 지식에 대한 확신감을 갖고 정신적 경계를 강 화하여 위협정보가 경계의 내부로 들어오는 것을 방어하고 위 협적인 정보에 대한 인지적 왜곡이 촉발될 수 있다(Chaxel, 2016). 따라서 의사결정에서 소비자가 새로운 위협정보에 직 면하더라도 사전에 선호된 대체안이 결정안으로 확정될 수 있 다(Dekay, Stone, \& Miller, 2011; Meloy \& Russo, 2004; Russo, 2015).

그런데 정보의 선택적인 노출에 관한 연구(French, Hevey, Sutton, Kinmonth, \& Marteau, 2006; Niedernhuber, Kastenmueller, \& Fischer, 2014)는 개인적 신념이나 지식을 위협하는 정보가 정보처리의 정확성 목적을 상기시킬 수 있다 고 하였다. 정확성 목적은 정확한 정보처리행동을 더욱 할 수 있게 하여(Fischer, Kastenmuller, Greitemeyer, Fischer, Frey, \& Crelley, 2011), 위협정보에 노출된 소비자가 자신의 기존신 념을 확증할 정보를 탐색하는 확증적 편향성을 보일 확률이 낮아질 수 있다. 따라서 소비자가 새로운 위협정보에 직면하여 정확성 동기를 갖게 되면 결정안이 사전에 선호된 대체안과 다를 수 있다.

\section{3. 프라이드 유형과 타인의 불일치 정보에 대한 공감적 관심}

심리학에서 동감(sympathy)과 공감(empathy)을 메시지의 언 어적 내용이나 맥락에서 느끼는 감정적 절차(Strayer, 1987)로 이해했는데, Escalas and Stern(2003)은 동감과 공감은 모두 심리적 감정반응이지만 차이가 있다고 보고, 광고에 대한 감정 반응의 연구에서 동감과 공감을 구별하였다. 동감은 자신의 인 지에 기초하여 '나'의 의식을 강조(Wispé, 1986)하지만, 공감은 타인의 감정을 자신의 감정으로 경험하여(Eisenberg \& Strayer, 1987 타인의 감정과 나의 감정이 같게 되는 상태를 의미한다.

타인의 의견에 대한 동감, 동정심, 관심 등으로 설명되는 공 감적 관심성이 높(낮)을수록, 타인의 의견에 대한 부정적 편견 을 통제하려는 동기 수준이 높(낮)아지고 자신의 사고를 지지 하는 편향성(prejudice)이나 차별성(discrimination)이 억제(촉진) 되게 된다(Pettigrew \& Tropp, 2008). 공감적 관심성은 타인의 평가에서 부정적인 편견(bias)에 저항하는 방향으로 중요하게 작용하여, 편향성을 극복하게 할 수 있다. 그리고 타인과 유사 함을 느끼는 것이 타인의 의견에 대한 공감적 관심성을 유도 하는 중요한 변수가 될 수 있어서, 공감적 관심성은 소비자가 성공하지 못한 타인의 평가에서도 편견을 극복하게 하여 부정 적 편향성과 타인을 무시하는 차별성을 감소시킬 수 있다 (Dovidio, Johnson, Gaertner, Pearson, Saguy \& AshburnNardo, 2010; Galinsky \& Ku, 2004).
환경이 자신의 성과경험을 통제했다고 생각하면 통제의 주 도성을 외부 환경에서 찾는 것이고, 자신의 행동이 자신의 성 과경험을 만들었다고 생각하면 통제의 주도성을 자신의 내부 에서 찾는 것이다. 자기타당화는 소비자가 기억되는 자신의 생 각이 타당하다고 느끼고, 의사결정을 할 때 자신의 기존생각을 사용해도 된다는 기존사고에 대한 확신(thought confidence)이 다(Petty et al., 2002). 그리고 소비자가 자신의 환경을 통제할 수 있다는 생각은, 자신이 주도하여 환경을 관리할 수 있고, 환경이 운명적이라기보다 자신의 행동에 따라서 달라질 수 있 다는 기대로, 환경의 통제에서 자신의 주도성(locus of control) 에 관한 사고이다(Rotter, 1966). 외부환경의 주도관점에서 타 인을 이해하고 관심을 갖게 하는 동감적 관심성은 타인의 불 일치 정보에 대한 부정적 편향성을 억제하고(Pettigrew \& Tropp, 2008), 타인을 무시하는 차별성을 감소시킬 수 있다 (Dovidio et al., 2010; Galinsky \& Ku, 2004.). 타인에 대한 공 감적 관심은 운이 없는 타인에 관한 평가에서도 부정적 편향 성을 극복하는 동기를 갖게 한다(Finlay \& Stephan, 2000). 그 러나 타인과 공감하지 못하면 그 부정적 편향성을 통제하려는 동기가 약화되어 타인을 차별화하고 편파적인 부정적 평가를 할 수 있다(Glaser, Dixit, \& Green, 2002).

그런데 오만성 프라이드와 관련된 자질적 자아의 불안정성 과 불안정한 자존감은 자신에 대한 초점을 더 유도하고, 자기 중심적인 생각을 하게 하여(Crocker \& Park, 2004), 타인의 요 구를 수용하는 것을 억제할 수 있다. 오만성 프라이드를 느끼 는 소비자는 자신만의 자질에 초점을 두어, 자신을 방어하고 타인과 자신이 유사할 수 있다는 것을 지각하지 못하여 타인 과의 공감성이 낮고, 자신의 우월감이나 지배성을 표출할 수 있다. 그런데 타인도 투여할 수 있다고 생각하는 자신의 노력 에 기초한 참된 자아가치와 겸손함을 수반하는 진정성 프라이 드는 타인이 자신과 유사할 수 있고 서로 연결된 느낌을 촉진 하여 타인과 공감하고 타인의 요구를 수용하게 할 수 있다 (Joireman, Parrott, \& Hammersla, 2002). 오만성 프라이드를 느끼는 사람은 자신 또는 타인의 관점에서 지배성향은 있지만 품격이 없다고 할 수 있으며, 진정성 프라이드를 느끼는 사람 은 품격은 있지만 지배성향이 없다고 할 수 있다(Tracy \& Robins, 2014).

따라서 오만성 프라이드와 진정성 프라이드가 자신의 의견 과 다른 타인의 불일치 정보에 공감적 관심성을 서로 다르게 지각하게 할 수 있다. 즉 오만성 프라이드를 느끼는 소비자는 타인의 불일치 정보에 공감하지 못하고, 진정성 프라이드를 느 끼는 소비자는 타인의 불일치 정보에 공감할 수 있다.

가설1: 진정성 프라이드를 느끼는 소비자 보다 오만성 프라 이드를 느끼는 소비자가 타인의 불일치 정보에 대한 공감적 관심성이 낮을 것이다.

\section{4. 프라이드 유형과 정보처리 동기}

소비자의 태도와 관련된 정보의 처리에서 방어 동기는 표적 에 대한 자신의 기존의 태도, 신념, 또는 행위를 방어하게 하 고, 판단기준의 관점에서 제자리를 유지하게 하는 반면에, 정 확성 동기는 표적을 정확하게 평가하게 한다(Chaiken \& Eagly 1989; Hart, Albarracin, Eagly, Brechan, Lindberg, \& Merrill, 2009).

정확성 동기는 객관적이고, 진실을 발견하려는 열린 마음으 
로 정보를 처리하게 할 수 있다(Chaiken \& Eagly, 1989). 중요 한 성과와 관련되는 의사결정은, 성과와 관련된 관여도 (outcome-relevant involvement)를 높이고, 기존의 태도 또는 신념 보다 새로운 정보의 처리에 주의하게 하는 정확성 동기 를 촉발할 수 있다. 소비자가 성과를 내야 하는 것과 관련된 결정을 할 때에, 자신이 추구하는 가치와 관련된(valuerelevant involvement) 결정을 할 때와 비교하여, 방어 보다 정 확성에 관심을 갖고 정보를 객관적으로 처리하는 성향을 보인 다(Jonas \& Frey, 2003). 따라서 중요한 개인적인 성과와 관련 되는 정보를 처리하는 경우에 기존의 사고에 대한 일치성 편 향이 감소될 수 있다. 즉 정확성 동기는 소비자의 초기판단과 불일치 정보에 노출된 후의 최종판단 간에 차이가 크게 할 수 있다.

Dweck(2006)은 보편적인 귀인을 수행지향성(orientation toward performance) 관점으로, 그리고 구체적인 귀인을 과업 지향성(orientation toward task) 관점으로 접근하고, 수행지향 적인 사람은 실패를 유능하지 못하고 자아의 안정성이 부족하 여 유도된 결과로 보는 반면, 과업지향적인 사람은 자신이 행 한 행동에 초점을 두어 실패를 부정적 경험으로 간주하지 않 고 실패에서 자신을 책망하지 않으며, 실패를 학습경험으로 보 고, 차후에 유사한 과업에서는 성공할 수 있다고 확신하는 경 향이 있음을 연구했다. 과업지향적인 사람은 시간의 흐름 속에 서 경험하면서 능력을 학습하고 능력이 개선될 수 있다고 생 각한다.

성공에 보편적인 불변의 자질을 귀인 시키는 소비자는 자신 의 직무수행가능성에 초점을 두고 직무수행에서 자신의 능력 자질을 생각하며, 정보처리에서 자신을 방어하는 동기를 가질 수 있다. 반면에 성공에 자신이 행한 구체적인 노력행동을 귀 인시키는 소비자는 과업의 수행에 필요한 것을 배우고 능력을 갖추려는 학습목표를 갖고 과업에 이용할 수 있는 정확한 지 식이나 재능을 습득하려 할 수 있다. 따라서 성공에 구체적인 노력행동을 귀인시키는 소비자는 정보처리에서 정확성 동기를 더욱 갖게 된다고 볼 수 있다.

오만성 프라이드를 느끼는 소비자는 자신의 불변적 자질에 초점을 두고 자신이 타인과 다르다고 생각하여 타인과 자신 간의 유사성을 지각하지 못한다. 자신의 의견과 다른 타인의 새로운 불일치 정보에 노출되었을 때에, 자신에 대한 방어적 초점을 갖고 타인의 의견을 무시할 수 있다. 그런데 자신이 투 여한 노력을 타인도 투여할 수 있다고 생각하여 타인과 자신 이 유사할 수 있음을 지각하게 할 수 있는 진정성 프라이드를 느끼는 소비자는 자신의 신념이나 의견과 다른 타인의 새로운 불일치 정보에 노출되었을 때에, 판단의 정확성에 초점을 두고 타인의 의견을 수용할 수 있다.

가설2: 오만성 프라이드를 느끼는 소비자가 진정성 프라이 드를 느끼는 소비자 보다 정보의 처리에서 정확성동 기 보다 방어동기를 갖게 될 것이다.

\section{5. 프라이드 유형과 불일치 정보에서 판단의 차이}

오만성 프라이드와 진정성 프라이드가 타인의 부정적인 의 견에 노출되었을 때, 서로 다른 판단을 유도할 수 있다. 오만 성 프라이드를 느끼는 소비자와 비교하여 진정성 프라이드를 느끼는 소비자는 타인의 의견에 공감할 수 있고, 타인에 대한 부정적 편견과 차별화를 지양하고 부정적인 평가 편향성을 극
복하여 자신의 초기 신념에 타인의 의견을 반영하여 자신의 최종 판단이 초기판단과 다를 수 있다. 그런데 오만성 프라이 드를 느끼는 소비자는 타인의 의견에 공감성이 낮고 타인의 의견을 고려하지 않고, 부정적인 평가 편향성을 극복하지 못하 여, 자신의 초기판단과 최종판단 간에 차이가 없을 수 있다.

가설3: 초기의 판단 이후에 타인의 불일치 정보에 노출되었 을 때, 초기의 판단과 최종 판단 간의 판단차이 값 은 진정성 프라이드를 느끼는 소비자 보다 오만성 프라이드를 느끼는 소비자에게 작을 것이다.

오만성 프라이드는 자기중심적인 생각과 자아의 불안정성을 유도하여(Crocker \& Park, 2004), 자신을 방어하고 자신만의 자질에 초점을 두어, 자신의 우월감을 표출하고 타인의 불일치 의견에에 공감성이 낮을 수 있다. 그런데 진정성 프라이드는 자신이 행한 노력을 타인도 수행할 수 있다고 생각하고 타인 도 자신과 유사할 수 있다는 겸손함을 수반하여 타인과 공감 하게 할 수 있다(Joireman, Parrott, \& Hammersla, 2002). 따 라서 오만성 프라이드와 진정성 프라이드가 타인의 불일치 정 보를 처리하는 과정에서 타인에 대한 공감적 관심성을 매개로 판단에 서로 다른 역할을 할 수 있다. 즉 오만성 프라이드를 느끼는 소비자는 타인의 의견에 공감하지 못하고 타인의 불일 치 정보를 부정적으로 평가하고 무시할 수 있고, 진정성 프라 이드를 느끼는 소비자는 타인의 의견에 공감하여 타인의 불일 치 정보를 긍정적으로 평가할 수 있다. 오만성 프라이드를 느 끼는 소비자와 비교하여 진정성 프라이드를 느끼는 소비자는 타인의 불일치 정보에 공감적 관심성이 높고 타인에 대한 부 정적 편견과 차별화를 지양하고, 부정적인 평가 편향성을 극복 하여, 자신의 초기 신념에 타인의 의견이 반영되어 초기의 판 단과 최종 판단 간에 차이가 커질 수 있다. 소비자가 타인의 불일치 정보에 접했을 때, 프라이드유형의 초기판단과 최종판 단 간의 차이효과에 공감적 관심성이 매개역할을 할 수 있다.

가설4: 초기의 판단 이후에 타인의 불일치 정보에 노출되었 을 때, 공감적 관심성이 초기의 판단과 최종 판단 간의 판단차이 값에 긍정적인 영향을 주어, 소비자 가 느낀 프라이드유형의 판단차이 값 효과에 공감적 관심성이 매개역할을 할 것이다.

한편, 기존의 신념을 유지하고 정신적 방어(Hart, 2014)를 하는 보상적 정보처리는 자신의 지식구조에서 정신적 경계를 유지하여, 자신의 기존의 지식체계의 질서와 구조를 지속시키 려 한다(Cutright, Bettman, \& Fitzsimons, 2013; Cutright, 2012). 기존의 지식체계에 대한 위협정보에서 기존의 지식의 경계를 강화하여 경계의 내부로 위협정보의 유입을 방어하고 왜곡적 인지를 할 수 있다(Chaxel, 2016). 그런데 정보의 처리 에서 정확성 동기에 의한 정확한 정보처리는 위협정보에서 기 존신념에 대한 확증적 편향성이 낮을 수 있다(Fischer et al., 2011). 따라서 소비자의 정확성 동기는 새로운 위협정보에 의해 최종적인 결정안이 사전의 선호대체안과 다르게 할 수 있다.

오만성 프라이드를 느끼는 소비자와 진정성 프라이드를 느 끼는 소비자, 즉 프라이드의 유형에 따른 초기판단과 최종판단 간의 차이가 자신의 의견과 불일치하는 정보를 처리하는 동기 에 의해 조절될 수 있다. 진정성 대비 오만성 프라이드를 느끼 는 소비자는 새로운 위협정보에 직면하더라도 최종적인 의사 
결정에서사전에 선호된 대체안이 결정안으로 확정할 수 있는 데(Dekay et al., 2011; Meloy \& Russo, 2004; Russo, 2015), 소비자의 방어동기는 진정성 대비 오만성 프라이드를 느끼는 소비자에게 사전에 선호된 대체안이 최종선호안이 되도록 더 욱 촉진할 수 있다.

가설5: 초기의 판단 이후에 타인의 불일치 정보에 노출되었 을 때, 소비자가 느낀 프라이드유형에 따른 초기의 판단과 최종 판단 간의 판단차이 값이 동기유형에 의해 조절될 것이다. 오만성 프라이드를 느낀 소비 자가 정확성 동기보다 방어동기에서 판단차이 값이 더욱 작을 것이다.

\section{6. 동기유형에 따른 자기타당화와 판단의 차이}

소비자의 기존 신념이나 지식을 위협하는 새로운 불일치 정 보가 정보처리의 정확성 목적을 상기시켜서 정확한 정보처리 행동을 유도할 수 있다. 불일치 위협정보는 자신의 환경통제력 에 대한 위협을 고지할 수 있고, 정보처리에서 자기확증적 정 보탐색을 제약하는 정확성 목적을 활성화시킬 수 있다(Fischer et al., 2011). 소비자가 신중하게 정보를 처리하는 마음가짐을 갖게 하고 자신의 기존 신념에 대한 타당화 수준을 약화시켜 서 기존의 신념에 편향하는 확증적 정보 탐색을 감소시킬 수 있다. 그런데 기존의 신념과 불일치하는 위협적인 단서정보는 삶이 불확실하고 어떤 것이 잘못 되고 있다는 것을 상기시킬 수 있는 정보가 될 수 있다. 위협정보의 탐색으로 환경상황을 적절하게 평가하는 경우에 환경을 더 효과적으로 통제할 수 있지만, 소비자가 새로운 위협정보에 저항하여 자신을 방어하 는 것이 자신의 신념이나 지식 구조를 유지하는 효과적인 전 략일 수 있다. 따라서 타인의 위협적인 새로운 불일치 단서정 보에서 정확성 동기보다 방어 동기가 자기타당화를 촉진할 수 있다.

가설6: 타인의 불일치 정보에서 소비자의 정확성 동기와 비교 하여 방어 동기가 자기타당화 수준을 촉진할 것이다.

내부 주도성 소비자는 갈등정보에 노출되었을 때에 기존의 신념을 강화하여 그 정보의 영향에 저항하는 성향이 있다 (Brehm, 1966; Biondo \& MacDonald, 1971). 새로운 불일치 정보에 노출되었을 때에 기존의 선호안에 대한 확신성과 선호 지지 편향(preference supporting bias) 간에 긍정적인 관계 (Carlson \& Russo, 2001; DeKay, Stone, \& Sorenson, 2012) 는 소비자의 주위환경에 존재하는 타인의 설득 메시지보다 자 신의 기존사고에 더 주의하여 기존의 지식구조를 유지하는 정 신적 방어의 관점과 상통한다. 외부에서 주도성을 찾는 소비자 보다 내부에서 주도성을 찾는 소비자가 외부의 불일치정보에 저항하는 방어 동기를 갖는 성향에 의해서, 선택결정과정에서 기억되는 기존 선호도의 강도가 기존의 선호 대체안에 대한 확신성을 유도할 수 있고, 자기타당화 성향을 촉진하여, 기존 의 선호도와 다른 새로운 불일치 정보에 노출되어도 기존의 선호 대체안이 최종 결정안이 되게 할 수 있다(DeKay et al., 2011; Russo, 2015), 따라서 다음의 가설을 설정한다.

가설7: 타인의 불일치 정보에서 소비자의 자기타당화 정도 는 소비자의 초기판단과 최종판단 간의 차이에 부정
적인 영향을 미칠 것이다.

이상의 가설들은 <Figure 1>로 요약된다.

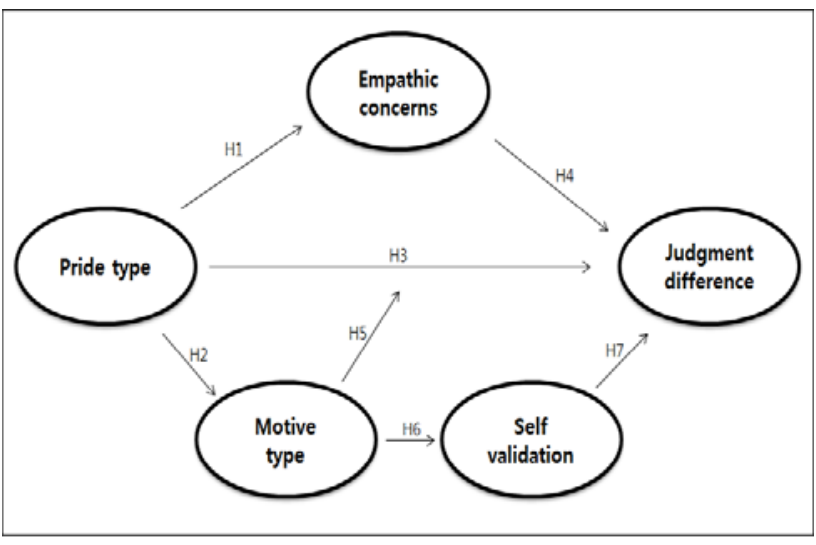

Figure 1: Summary of Hypotheses

\section{3. 연구방법}

3.1. 실험설계, 실증대상 제품의 선정 그리고 구성개념 의 측정

본 연구는 사전에 오만성 프라이드를 느끼는 소비자와 진정 성 프라이드를 느끼는 소비자 간에 불일치정보에 대한 처리동 기와 공감적 관심에 차이가 있을 수 있다고 본다. 따라서 본 연구는 소비자가 기존선호에 일치되는 정보에 노출되는 경우 와 불일치되는 정보에 노출되는 경우 간에 초기판단과 최종판 단의 차이를 탐색하고 프라이드의 유형에 의해 판단 차이가 조절되는가를 식별할 필요가 있다. 프라이드의 유형과 정보의 유형을 구분하여 실험의 설계는 2(노출정보의 유형: 일치 vs. 불일치 $) \times 2$ 프라이드의 유형: 오만성 프라이드 vs. 진정성 프 라이드)의 집단 간 설계를 하고, 연구자가 재직하는 대학의 학 부생을 피험자의 모집단으로 설정하였다.

그리고 실증조사는 예비조사, 사전조사, 본 조사로 나누어 진행하는데, 피험자들이, 제품브랜드에 대한 자신의 기존의 선 호도와 불일치되는 타인의 정보에 관심을 좀 더 갖게 되는 제 품은 고관여 제품이기 때문에, 과거에 제품브랜드의 판단과 선 택을 한 경험이 있는 고관여 제품을 실증대상 제품으로 선정 할 필요가 있다. 따라서 예비조사에서 실증대상 제품을 고관여 제품이면서 피험자들이 과거에 사용한 경험이 있는 제품을 탐 색하고, 일치 및 불일치 정보메시지의 구성을 위해서 제품브랜 드의 평가에 이용하는 속성과 속성의 중요도를 탐색하였다. 예 비조사에서 30 명의 학부생을 대상으로 관심이 있고 중요하며 사용경험이 있는 제품을 조사한 결과에서 디지털 카메라를 23 명의 학생이 선정하였다. 그리고 디지털 카메라브랜드의 평가 에 이용하는 속성을 조사한 결과에서 8개의 디지털 카메라 제 품속성이 탐색되었는데, 4 개의 중요한 제품속성, 즉 보정기능, 컴퓨터 호환성, 배터리 형태와 수명, 내구성과 4개의 비교적 중요성이 떨어지는 속성, 즉 줌 기능, 스크린 크기, wide-angle 
렌즈, GPS 내장이 식별되었다. 사전 및 본 조사에서 제품의 브랜드 명은 $\mathrm{A}$ 와 $\mathrm{B}$ 로 표기하여 판단에 영향을 미칠 수 있는 브랜드명의 효과를 제거하였다.

실증조사를 위해 사전의 성공에 소비자가 성취감을 느끼고, 오만성 프라이드 또는 진정성 프라이드를 느끼게 하는 과정을 설계하고, 기존선호에 일치 및 불일치되는 정보메시지를 개발 하여 조작하였다. 그리고 오만성 프라이드와 진정성 프라이드 의 측정, 성취감의 측정, 초기판단의 측정, 정보처리의 동기와 노출정보에 대한 공감적 관심, 자기 타당화와 최종판단을 측정 하고, 그리고 초기판단과 최종판단 간의 차이, 즉 판단 차이를 계산하였다.

\section{2. 프라이드를 유형별로 느끼는 과정의 설계와 성취감, 귀인 및 프라이드의 측정}

프라이드를 유형별로 느끼는 과정의 설계에서 진정성 프라 이드를 느끼게 하는 과정은 Ashton-James and Tracy(2012)과 Tracy and Robins(2007)가 사용한 방법을 이용하여 설계하였 다. 피험자들에게 과거에 과업을 달성하기 위하여 열심히 일을 하고 노력하여 업적을 내고 중요한 목적을 달성하여 성공했던 이벤트를 기억하고 기술하게 하였다. 그리고 그 이벤트에서 우 수한 업적의 실현으로 목적을 달성하기 위해서 그들이 무엇을 했는가(what they did), 타인과 정보를 얼마나 교류했는가, 그 리고 얼마나 노력을 했는가 등을 기술하게 하였다.

이벤트의 기술에서 주의정도를 7 점척도 $1=$ 전혀 그렇지 않 다, $7=$ 매우 그렇다)에 의해 '매우 주의' '매우 집중' ‘몰입'으로 로 측정하고, 성취감은 중요한 목적의 달성에 의해 느겨지는 감정이기 때문에(Giner-Sorolla, 2001; MacInnis \& Patrick, 2006), Zhang, Chan, and Guan(2013)이 목적달성정도의 측정 에 사용한 척도를 이 연구의 목적에 맞게 수정하여 '나는 이 이벤트에서 실질적으로 나의 목적을 달성하였다', '나는 이 이 벤트에서 목적의 달성정도에 만족한다', '나는 이 이벤트에서 내가 달성하려는 목적을 달성했다', '나는 이 이벤트에서 나의 목적을 충분히 성취했다'를 7점척도로 측정하였다. 성공에 노 력 또는 자질의 귀인은 '작성하신 이벤트의 성공의 원인으로 생각되는 것을 아래에서 하나만 선택하여 주세요'의 유도문장 과 함께 (1) 내가 일을 열심히 하고 노력한 것이다 (2) 나의 갖 춰진 타인과 차별화될 수 있는 우수한 자질이다 (3) 기타'에서 하나를 선택하게 하고, (1)이 아닌 (2)나 (3)을 선택한 설문지를 제거하는 필터문항으로 사용하였다. 그리고 Ashton-James and Tracy(2012)의 척도를 이용하여 진정성 프라이드를 느끼 는 정도를 측정하였다. 진정성 프라이드를 느끼는 정도를 '내 가 노력해서 목적이 달성되었다(accomplished)고 느낀다', '내 가 노력해서 목적을 성취하였다(achieving)고 느낀다', '이 이벤 트에서 자부심을 느꼈다(confident)', '내가 노력해서 목적이 충 족되었다(fulfilled)고 느낀다', '나의 노력은 생산적이었다 (productive)고 느낀다', '이 이벤트는 내 노력이 가치가 있음을 느끼게 했다(having self-worth)', '내가 노력한 이 이벤트는 매 우 성공적이었다(successful)고 느낀다'를 7점 척도로 측정하였 다.

한편 오만성 프라이드를 느끼게 하는 과정도 Ashton-James and Tracy(2012)과 Tracy and Robins(2007)가 사용한 방법을 이용하였다. 피험자들에게 자신의 타고난 지능, 자질 등을 기 술하게 한다. 그리고 과거에 직무의 수행에서 자신의 지능, 자 질 등이 작용하여 중요한 목적을 달성하고, 타인에게 뽐내고
거드름을 피우며 나니까 이렇게 할 수 있다는 행위를 한 이벤 트를 기억하고 기술하게 하였다. 그 이벤트에서 목적달성의 중 요요인을 주관식으로 기술하게 하였다. 자신이 누구인가(who they are)를 기술하게 하였다. 이 과정에서 기술관여도, 성공에 노력과 자질 중 무엇이 귀인되는가, 그리고 성취감의 측정은 앞서 진정성 프라이드에서 기술한 측정문항을 이용하였다. 그 리고 Ashton-James and Tracy(2012)의 척도를 이용하여 오만 성 프라이드를 느끼는 정도는 '그 이벤트를 떠올리면, 나는 뭐 든지 다 할 수 있는 능력자로 생각된다(conceited),' '그 이벤트 에서 내 자신이 대단하게 느겨진다(arrogant),' '이 성공의 중심 에는 내가 있었음을 느낀다(egotistical)', '이런 성공은 나니까 할 수 있다고 느겨진다(pompous),' '그 이벤트를 떠올리면, 나 는 다른 사람들에게 나의 재능(능력)을 자랑하고 싶어진다 (smug),' '나는 남들과 품격이 다르다고 느껴진다(snobbish),' '그 이벤트를 떠올리면, 나는 내 자신을 자랑하면서 으스대고 싶다(stuck-up)'의 문항을 7점 척도로 측정하였다.

\section{3. 제품 브랜드 별로 속성정보의 제시 및 첫 번째 조사와 초기판단의 측정}

Jain and Maheswarean(2000)의 연구와 Jain(2003)의 연구 를 참고하여, 최초(초기)판단을 측정하기 위한 조사가 진행되 었다. 피험자에게 최초(초기)판단의 측정 전에 '제품브랜드에 대한 의사결정에에 관한 실증조사를 하는데, 실증조사는 2 회 의 조사로 진행된다'고 설문지에 표기하여 고지하였다.

설문지에서 피험자는 '첫 번째 조사'의 표기에 노출되고, 조 사설문에 응답하게 하였다.

예비조사에서 탐색된 디지털 카메라의 평가에 이용되는 8 개 의 제품속성, 즉 4 개의 중요한 제품속성과 4 개의 비교적 중요 성이 떨어지는 속성의 정보가 제시되었다. 피험자들에게 '제품 브랜드 $A$ 와 $B$ 는 서로 다른 회사에서 제작한 신형 포터불 디 지털 카메라이고 가격은 15 만 원으로 같다. 대학의 연구팀이 과학적인 분석으로 디지털 카메라 $\mathrm{A}$ 와 $\mathrm{B}$ 의 속성정보를 철저 히 파악을 하여 작성하였다'는 메시지를 노출시키고, 피험자들 이 제품브랜드 $\mathrm{A}$ 에 대한 강한 최초의 선호도를 형성하도록, 4 개의 중요한 제품속성 중에서 3 개 그리고 4 개의 비교적 중요 성이 떨어지는 속성 중에서 2 개에서 디지털 카메라 $\mathrm{A}$ 가 $\mathrm{B}$ 보 다 좋다는 제품정보 설명서를 작성하였다. 피험자가 $\mathrm{A}$ 와 $\mathrm{B}$ 로 표기된 서로 다른 두 개의 브랜드 설명서에 주의하여 읽게 했 다.

그리고 $\mathrm{A}$ 와 $\mathrm{B}$ 의 브랜드에 대한 피험자의 평가는 Jain and Mahecwaran(2000)의 측정문항을 토대로 'B가 매우 좋음(1)/A 가 매우 좋음(7), B가 매우 바람직함(1)/A가 매우 바람직함(7), $\mathrm{B}$ 가 매우 유용함(1)/A가 매우 유용함(7), B에 매우 호감이 감 (1)/A에 매우 호감이 감(7)'의 네 개 문항에 응답하게 하여 측 정하였다. 그리고 피험자에게 '이 평가는 귀하 자신의 초기판 단입니다, 기억하세요'를 표기하여 기억하게 했다.

\section{4. 구성개념의 측정과 정보의 제시 및 두 번째 조사}

\subsection{1. 처리 동기의 식별 측정}

피험자들은 실험설계집단별로 초기판단과 일치 또는 불일치 정보를 읽고 난 후에, 정보의 처리동기를 식별하는 설문에 응 답한다. 처리동기의 식별에서, Carlson, Tanner, Meloy and 
Russo(2014)와 Chaxel(2016)의 연구를 참고하여, 방어동기, 정 확성 동기, 그리고 주의분산을 유발할 수 있는 기억 동기를 의 미하는 다음의 제시 문을 읽게 하고, 3 개의 제시 문들 중에서 피험자의 생각에 일치하는 하나를 선택하게 하였다. 선택한 제 시 문이 피험자의 동기를 의미한다. 그리고 기억 동기 제시 문 을 선택한 피험자는 분석에서 제외되는 필터문장으로 이용되 었다.

(1) 방어 동기 제시 문: 나의 과거(초기)판단에서 좋고 바람 직하고 유용하며 호의적으로 판단을 한 브랜드를 지지한 다. 나는 타인이 제시하는 모든 정보에 주의할 필요가 없다고 생각하고 선택적으로 처리하며, 나의 처음 초기 판단을 지지한다.

(2) 정확성 동기 제시 문: 나는 다른 소비자의 판단이 반영 된 모든 정보를 신중하게 처리하여, 어떤 브랜드를 선호 할 것인가를 정확하게 결정하고 싶다. 나의 과거판단 보 다 타인의 정보를 신중하게 처리하여, 나의 현재선호를 결정하기를 원한다.

(3) 기억 동기 제시 문: 나는 내가 접한 정보를 잘 기억하려 고 한다.

\subsection{2. 타인의 정보에 대한 공감적 관심과 자기타당화의 측정}

Escalas and Stern(2003)은 동감과 공감의 차이를 식별하였 고, Dovido et al.(2010)은 공감적 관심성을 동감, 동정, 관심으 로 설명하였다. 따라서 공감적 관심성의 측정에서, 동감반응의 측정으로 '나는 다른 소비자의 평가에 동감한다,' '나는 나와 다른 소비자의 의견에 동감한다,' 동정반응의 측정으로 '나는 나와 다른 평가를 한 소비자에 동정한다,' '나는 나와 다른 의 견을 준 소비자에 동정한다,' 그리고 관심반응의 측정으로 '나 는 나와 다른 소비자의 평가에 관심을 갖는다,' '나는 나와 다 른 소비자의 의견에 관심을 갖는다'의 문항을 이용한다. 그리 고 공감측정으로 '나는 나와 다른 소비자의 평가를 나의 평가 로 경험한다,' '나는 나와 다른 소비자의 의견이 반영된 정보를 나의 정보로 경험한다’의 문항을, 7점 척도(전혀 그렇지 않다 (1), 매우 그렇다(7))를 이용하여 측정하였다.

자기타당화 정도를 측정하기 위해서, Chaxel(2016)이 확신 성의 평가측정에서 이용한 척도를 참고하여, '나의 초기 판단 에 이용된 속성의 관점에서 $\mathrm{A}$ 의 우수성에 대해 지금도 확신한 다,' 'A가 현재도 선도하는 브랜드임에 대해 확신한다,' 'A 브랜 드 자체에 대해 확신한다' 를 7점 척도(전혀 그렇지 않다(1), 매우 그렇다(7))를 이용하여 측정하였다.

\subsection{3. 일치 또는 불일치정보의 제시}

피험자들은 설문지에서 '두 번째 조사'의 표기에 노출되고, 두 번째 조사설문에 응답하게 하였다. 실험설계에서 기존의 선 호 브랜드와 일치(불일치)하는 정보 집단의 피험자는 일치(불 일치)하는 정보에 접하고 읽게 된다. Agrawal et al.(2013)의 연구에서 사용된 방법을 이용하여, 피험자가 제품을 사용하는 다른 소비자들의 의견이 퍼센트(\%)로 제시되는 정보를 읽게 하였다. 기존(초기)의 선호와 일치하는 정보에서는 브랜드A가 브랜드B 보다 6 개의 속성(첫 번째 조사에서 8 개 속성의 부분 집합) 중에서 4 개의 속성에서 타인 소비자들이 $\mathrm{A}$ 가 B 보다 우 수함을 보여주는 응답비율을 $86 \%, 91 \%, 24 \%, 88 \%, 20 \%$, $90 \%$ 의 정보로 제시하여, 절대다수의 속성에서 $\mathrm{A}$ 가 $\mathrm{B}$ 보다 성
능이 좋음을 표현하였다. 그리고 기존(초기)의 선호에 불일치 하는 정보에서 6 개의 각 속성에 대하여 B가 A보다 우수하다 고 한 응답비율이, $100 \%$ 에서 선호일치정보에서 제시된 각 속 성의 퍼센트 값이 차감되어, $14 \%, 9 \%, 76 \%, 12 \%, 80 \%, 10 \%$ 의 정보가 제시되었다. 따라서 선호불일치정보는 절대다수의 속성에서 다른 소비자들이 $\mathrm{B}$ 가 $\mathrm{A}$ 보다 성능이 좋음을 표현한 것이다.

두 번째 조사에서 타인의 의견이 \%로 반영된 정보가 피험 자 자신의 초기판단과 불일치-일치되는 정도를 7점 척도(매우 불일치/서로 완전히 다름(1), 매우 일치/서로 완전히 같음(7))를 이용하여 측정하였다.

\subsection{4. 최종판단의 측정과 초기판단과의 차이 계산}

첫 번째 조사에서 브랜드A와 $\mathrm{B}$ 의 초기판단에 이용한 네 개 문항으로 최종판단도 측정하였다. 초기판단 값과 최종판단 값 간의 판단차이(judgement change) 값은 브랜드 $A$ 에 대한 측정 문항별로 초기판단 값에서 최종판단 값을 차감하여 계산된다. 판단차이의 값은 초기판단 값과 두 번째 조사에서 일치정보에 노출된 후의 최종판단 값 간의 차이 값과 초기판단 값과 불일 치정보에 노출된 후의 최종판단 값 간의 차이 값으로 구분되 며, 초기판단 값의 변화를 의미한다.

\section{4. 자료의 수집 및 기초분석과 가설의 검증}

\section{1. 자료의 수집과 기초분석}

\subsection{1. 자료의 수집}

사전조사에서 실험설계의 집단별로 20 명씩, 80 명의 학부생 을 배정하였다. 관련된 설문지를 배포하고 점검하여 발견된 오 타, 미완성의 문장 등을 수정하고, 실험설계의 집단별로 네 유 형의 본 설문지를 완성하였다. 본 설문지에 의해 본 조사가 진 행되었다. 본 조사에서 네 개의 실험집단별로 마케팅관련과목 을 수강하는 학부생을 70 명씩 배정하고, 집단별로 관련된 설 문지를 배포하였다. 설문조사의 단위별로 설문이 끝나고 난 후 에 추첨으로 오천 원 상당의 문화상품권이 배부됨을 사전에 고지하고, 설문 후에 추첨하여 오천 원 상당의 문화상품권을 추첨하여 증정하였다. 총 280 부의 설문지를 회수하고, 각 설문 지를 면밀히 검토하여 성공에 노력 또는 자질의 귀인을 측정 하는 문항에서 오류를 범한 경우와 동기의 선정에서 기억동기 를 선정한 설문지, 그리고 디지털 카메라를 사용한 경험이 없 다고 응답한 설문지를 제거하였다. 최종적으로 진정성 프라이 드와 일치정보(65), 진정성 프라이드와 불일치정보(67), 그리고 오만성 프라이드와 일치정보(56), 오만성 프라이드와 불일치정 보(64)의 설문자료가 실증분석에 이용되었다.

\subsection{2. 기초분석}

이벤트기술에서 관여도 측정문항(.921), 성취감 측정문항 (.919), 각각의 $\alpha$ 값을 식별하여 내적 신뢰도(internal reliability) 를 탐색하고 합산평균하여, 실험설계 집단 간에 관여도 $(\mathrm{F}=1.618, \mathrm{p}>.05)$ 와 성취감 $(\mathrm{F}=2.397, \mathrm{p}>.05)$ 의 차이를 분산분 석하여 평균의 차이가 통계적으로 의미가 없음을 식별하고 혼 돈효과(confound effects)의 가능성이 없음을 탐색하였다. 오만 
성(진전성) 프라이드 집단에서 오만성 $(\alpha=.794)($ 진정성 $(\alpha=.885))$ 프라이드를 느끼는 정도를 7점척도의 중앙 값(4)에서 긍정의 방향으로 편향된 정도를 $\mathrm{t}$-분석하여 오만성 $(\mathrm{t}=5.884, \mathrm{p}<.05$ )(진 정성 $(\mathrm{t}=24.135, \mathrm{p}<.05))$ 을 확인하였다. 그리고 두 번째 조사에 서 첫 번째 조사의 정보와 일치하는 일치정보설계집단 $(\mathrm{M}=4.8058)$ 과 불일치정보설계집단 $(\mathrm{M}=2.2710)$ 간에 제시된 정 보의 유사성 $(\alpha=.869)$ 이 서로 다름을 식별하였다 $(\mathrm{t}=15.174$, $\mathrm{p}<.05)$. 동기의 유형을 방어동기(1)와 정확성 동기(-1)로 더미 처리하였으며, 타인에 대한 공감적 관심성 $(\alpha=.798)$, 자기타당 화 수준 $(\alpha=814)$, 그리고 브랜드 $\mathrm{B}$ 보다 $\mathrm{A}$ 를 선호하는 정도의 초기판단 $(\alpha=.832)$ 과 최종판단 $(\alpha=.961)$ 에 대하여 각각의 내적신 뢰도를 점검하고 합산평균하였다. 그리고 초기판단에서 브랜드 $\mathrm{B}$ 보다 $\mathrm{A}$ 를 선호하는 정도를 4점을 기준으로 독립표본의 $\mathrm{t}$-분 석하여 $\mathrm{A}$ 가 $\mathrm{B}$ 보다 선호됨을 확인하였다 $(\mathrm{M}=5.4256, \mathrm{t}=24.724$, $\mathrm{p}<.05$ ).

Table 1: Judgment Change at Each Experimental Group

\begin{tabular}{|c|c|c|c|c|c|}
\hline & \multicolumn{5}{|c|}{ Dependent: Judgment Change } \\
\hline & Pride & Information & Average & S.D & $\mathbf{N}$ \\
\hline & \multirow{3}{*}{ Authentic } & consistency & $.1692(5.4538-5.2846)$ & .74753 & 65 \\
\hline & & inconsistency & 2.3694 (5.5522-3.1828) & 1.74749 & 67 \\
\hline & & Sum & $1.2860(5.5038-4.2178)$ & 1.74088 & 132 \\
\hline \multirow{6}{*}{1} & \multirow{3}{*}{ Hubris } & consistency & $.1161(5.2500-5.1339)$ & .74003 & 56 \\
\hline & & inconsistency & 1.2461 (5.4180-4.1719) & 1.34555 & 64 \\
\hline & & Sum & .7188 (5.3396-4.6208) & 1.23778 & 120 \\
\hline & \multirow{3}{*}{ Sum } & consistency & $.1446(5.3595-5.2149)$ & .74145 & 121 \\
\hline & & inconsistency & $1.8206(5.4866-3.6660)$ & 1.65694 & 131 \\
\hline & & Sum & $1.0159(5.4256-4.4097)$ & 1.54554 & 252 \\
\hline
\end{tabular}

Table 2: Interaction of Pride and Information

\begin{tabular}{|c|c|c|c|c|c|}
\hline Source & $\begin{array}{c}\text { Sum of } \\
\text { Squares }\end{array}$ & df & $\begin{array}{c}\text { Mean } \\
\text { Square }\end{array}$ & F & p \\
\hline Corrected Model & $218.071 \mathrm{a}$ & 3 & 72.690 & 47.255 & .000 \\
Intercept & 238.528 & 1 & 238.528 & 155.063 & .000 \\
Pride(P) & 21.697 & 1 & 21.697 & 14.105 & .000 \\
Information(I) & 173.849 & 1 & 173.849 & 113.016 & .000 \\
$\mathrm{P} \times \mathrm{I}$ & 17.952 & 1 & 17.952 & 11.671 & .001 \\
Error & 381.490 & 248 & 1.538 & & \\
Total & 859.625 & 252 & & & \\
Corrected Total & 599.562 & 251 & & & \\
\hline
\end{tabular}

$\mathrm{R}^{2}=.364$ (Adjusted $\mathrm{R}^{2}=.356$ )

실험설계의 유형별로 집단을 구분하여 초기판단에서 최종판 단의 차감값(판단차이)이 서로 다른가를 프라이드 유형과 정보 의 일치 대비 불일치의 이원배치로 분산분석하여, 통계적으로 유의적인 차이가 있음을 <Table $1>$ 및 <Table 2>와 같이 식 별하였다. 특히 프라이드 유형과 정보유형 간의 상호작용효과 가 유의적으로 탐색되어, 프라이드 유형에 따른 판단차이가 정 보유형에 의해 조절됨을 식별하였다. 진정성 프라이드집단 $(\mathrm{M}=1.2860)$ 이 오만성성 프라이드집단 $(\mathrm{M}=.7118)$ 보다 차감값(판 단차이)이 크고( $\mathrm{F} 1,248=14.105, \mathrm{P}<.05)$, 정보의 불일치집단 $(\mathrm{M}=1.8206)$ 이 일치집단 $(\mathrm{M}=.1446)$ 보다 차감값(판단차이)이 큰 것으로 $(\mathrm{F} 1,248=113.016, \mathrm{P}<.05)$ 분석되었으며, 프라이드집단 과 정보일치 대비 불일치집단 간의 상호작용효과 $(\mathrm{F} 1$, $248=11.671, p<.05)$ 가 의미가 있는 것으로 탐색되었다. 즉 정 보의 불일치집단과 일치집단 간의 차감값(판단차이)이 프라이
드의 유형집단에 의해 조절되는 것을 탐색하였다.

\section{2. 가설의 검증}

가설 1 을 검증하기 위하여 프라이드의 유형집단 간에 타인 에 대한 공감적 관심성 정도의 차이를 분산분석하였다. 공감적 관심성 정도가 오만성 프라이드집단( $\mathrm{M}=4.2771)$ 과 진정성 프라 이드집단(M=4.7756)이고, 차이가 의미가 있는 것으로 탐색되 었다( $F 1,250=27.379, p<.05)$. 따라서 가설 1은 지지되었다.

가설 2 의 검증에서 프라이드집단 간에 방어동기와 정확성동 기를 갖는 분포의 차이를 $\chi^{2}$-분석하였다. Table 3 의 프라이드 의 유형집단별 방어동기와 정확성동기의 선택분포에서 오만성 집단의 정확성동기 대비 방어동기의 선택비율 $(62 / 58)$ 이 진정성 집단의 정확성동기 대비 방어동기의 선택비율(42/90)보다 높 고, 분포의 차이분석에서 $x^{2}=10.217(p<.05)$ 가 유의적이어서, 가 설 2가 지지되었다.

Table 3: Frequencies of Motive Type Chosen at Each Pride Type

\begin{tabular}{|c|c|c|c|c|}
\hline \multicolumn{2}{|c|}{} & \multicolumn{2}{|c|}{ Motive } & \multirow{2}{*}{ Total } \\
\cline { 3 - 4 } \multirow{2}{*}{ Pride } & defense & accuracy & \\
\hline & authentic & 42 & 90 & 132 \\
\cline { 2 - 4 } & hubris & 62 & 58 & 120 \\
\hline \multicolumn{2}{|c|}{ Total } & 104 & 148 & 252 \\
\hline
\end{tabular}

$\chi^{2}=10.217 \quad(p<.05)$

가설 3 을 검증하기 위하여 초기의 판단 이후에 타인의 불일 치 의견정보에 노출된 집단을 대상으로 분산분석을 하였다. 오 만성 프라이드집단( $\mathrm{M}=1.2461)$ 과 진정성 프라이드집단 $(\mathrm{M}=2.3694)$ 간에 판단차이 값이 유의미하게 검증되었다 $(\mathrm{F} 1$, $129=16.882, p<.05)$. 따라서 가설 3 도 지지되었다.

가설 4 를 검증하기 위하여 타인의 불일치 정보에 노출된 실 험집단을 대상으로 프라이드유형을 진정성 프라이드(-1)와 오 만성 프라이드(1)로 더미처리하였으며, Process model 4 (Hayes, 2013)에 의해서 95\% 신뢰수준에서 매개분석하였다. Table 4의 분석결과에서 프라이드유형의 판단차이에 대한 직 접효과와 공감적 관심성의 매개효과(간접효과)는 하한계수 (LLCl)와 상한계수(ULCl)의 사이에 모두 0 이 포함되지 않아서 유의적으로 분석되었다. 즉 진정성(오만성) 프라이드보다 오만 성(진정성) 프라이드에서 공감적 관심성이 낮(높)고, 공감적 관 심성이 판단차이 값에 긍정적인 영향을 미치는 공감적 관심성 의 매개효과가 식별되었다. 따라서 가설 4는 지지되었다.

Table 4: Direct and Indirect Effects of Empathic Concern on Judgment Difference

\begin{tabular}{|c|c|c|c|c|c|c|}
\hline \multirow{2}{*}{ Direct } & effect & $\mathrm{SE}$ & $\mathrm{t}$ & $\mathrm{p}$ & $\mathrm{LLCl}$ & $\mathrm{ULCl}$ \\
\cline { 2 - 6 } & -.3951 & .1484 & -2.6627 & .0087 & -.6887 & -.1015 \\
\hline \multirow{2}{*}{ Indirect } & effect & \multicolumn{2}{|c|}{ Boot SE } & Boot LLCl & Boot ULCl \\
\cline { 2 - 6 } & -.1666 & .0728 & -.3364 & -.0429 \\
\hline
\end{tabular}

가설 5 를 검증하기 위하여 타인의 불일치 정보에 노출된 집 단을 대상으로 프라이드유형과 동기유형에 따른 판단차이 값 에 대하여 분산분석하였다. 진정성 프라이드의 방어동기 $(\mathrm{M}=2.3152)$, 오만성 프라이드의 방어동기( $\mathrm{M}=.6500)$, 진정성 프 라이드의 정확성동기 $(\mathrm{M}=2.3977)$ 오만성성 프라이드의 정확성 
동기(M=1.9655)로 판단차이 값이 분석되었고, 프라이드유형과 동기유형이 유의미하게 판단차이 값에 상호작용하여( $\mathrm{F} 1$, $127=5.186, p<.05)$ 오만성 프라이드의 방어동기에서 판단차이 값이 가장 작게 나타남을 입증하였다. 따라서 가설 5 가 지지 되었다.

가설 6 을 검증하기 위하여 방어동기(1)와 정확성 동기(-1)로 더미처리된 동기유형이 자기타당화 수준에 미치는 영향을, 불 일치 정보의 노출집단자료에 의해 회귀분석하였다. Table 5 의 분석결과에서 동기유형의 회귀계수(.232)가 $\mathrm{t}=2.982(\mathrm{p}<.05)$ 로 통계적으로 의미가 있어서 가설 6 이 채택되었다.

Table 5: Regression Coefficients of Motivation Type

Dependent: Self validity

\begin{tabular}{|c|c|c|c|c|c|}
\hline Model & $\mathbf{B}$ & $\mathbf{S E}$ & $\boldsymbol{\beta}$ & $\mathbf{t}$ & $\mathbf{p}$ \\
\hline constant & 5.118 & .078 & & 65.687 & .000 \\
motivation type & .232 & .078 & .254 & 2.982 & .003 \\
\hline
\end{tabular}

가설 7 의 검증에서, 판단차이에 자기타당화 수준의 영향을, 타인의 불일치 정보에 노출된 집단의 자료로 회귀분석 하였다. 회귀계수( $b=1.151, \mathrm{t}=1.395, \mathrm{p}>$.05)가 유의적이지 못하였다. 그 리고 더미처리된 동기유형이 자기타당화 수준을 매개변수로 판단차이에 미치는 영향을 간접경로를 설정하고, Process model 4 에 의해서 매개분석을 하였다. Table 6 의 분석결과에 서 동기유형의 판단차이효과에 대한 자기타당화의 매개(간접) 효과가 하한계수(LLCl)와 상한계수(ULCI)의 사이에 0이 포함되 어 비유의적으로 분석되었다. 따라서 가설 7 이 기각되었다.

그런데 동기유형의 판단차이에 대한 직접효과는 하한계수 (LLCl)와 상한계수(ULCl)의 사이에 0 이 포함되지 않아서 유의 적으로 분석되어, 가설 5 의 검증에서 지지된 결과와 맥을 같 이 한다.

Table 6: Mediation Roles of Self Validity in Motivation Type's Effect

\begin{tabular}{|c|c|c|c|c|c|c|}
\hline \multirow{2}{*}{ Direct } & effect & $\mathrm{SE}$ & $\mathrm{t}$ & $\mathrm{p}$ & $\mathrm{LLCl}$ & $\mathrm{ULCl}$ \\
\cline { 2 - 7 } & -.5221 & .1442 & -3.6195 & .0004 & -.8075 & -.2367 \\
\hline \multirow{2}{*}{ Indirect } & \multicolumn{2}{|c|}{ effect } & \multicolumn{2}{|c|}{ Boot SE } & Boot LLCl & Boot ULCl \\
\cline { 2 - 6 } & \multicolumn{2}{|c|}{.0642} & \multicolumn{2}{c|}{.0478} & -.0041 & .1881 \\
\hline
\end{tabular}

\section{5. 결론}

\section{1. 연구의 요약}

제품브랜드의 대체안에 대한 소비자의 기존(최초) 선호도판 단에 불일치하는 타인의 정보에 소비자가 노출되었을 때, 최종 선호도판단과 기존 선호도판단 간의 차이가 프라이드의 유형 에 따라 달라질 수 있음을 기존의 연구가 도외시한 점에 착안 하여, 이 연구는 프라이드의 유형을 구분하고 소비자가 자신의 기존 선호도판단에 불일치하는 타인의 정보에 노출되었을 때 제품브랜드의 대체안에 대한 소비자의 최종 선호도판단와 기 존(최초) 선호도판단 간의 판단차이에 환경적 프라이드의 유형 의 역할을 이론적으로 검토하고 가설을 설정하여 실증분석 하 였다. 또한 타인의 불일치정보에서 프라이드의 유형의 판단차
이 효과에서 타인의 불일치정보에 대한 공감적 관심도의 매개 역할과 동기유형의 상호작용효과, 동기유형의 판단차이 효과에 서 자기타당화의 매개역할을 이론적으로 검토하고 실증분석하 였다.

정보의 유형과 프라이드의 유형을 구분하여 2(노출정보의 유형: 일치 vs. 불일치 $) \times 2$ (프라이드의 유형: 오만성 프라이드 vs. 진정성 프라이드)의 집단 간 설계를 하고, 디지털 카메라 브랜드를 실증대상 제품 브랜드로 설정하여, 설문조사의 방법 으로 252명의 학부생 피험자에게서 수집된 자료로 설정한 가 설을 검증하였다. 실증분석의 결과는 다음과 같다.

첫째, 실험설계의 유형별 집단 간에 초기판단에서 최종판단 간의 판단차이가 식별되었다. 진정성 프라이드집단이 오만성 프라이드집단보다 판단차이 값이 크고, 정보의 일치집단보다 불일치집단의 판단차이 값이 큰 것으로 분석되었으며, 프라이 드 유형과 정보유형 간의 상호작용효과가 식별되었다.

둘째, 오만성 프라이드를 느끼는 집단이 진정성 프라이드를 느끼는 집단 보다 타인의 불일치 정보에 대한 공감적 관심성 이 낮고, 정보의 처리에서 정확성 동기보다 방어 동기를 갖는 것으로 탐색되었다.

셋째, 초기의 판단 이후에 타인의 불일치 정보에 노출되었 을 때, 진정성 프라이드집단보다 오만성 프라이드집단에서 판 단차이 값이 작았다.

넷째, 초기의 판단 이후에 타인의 불일치 정보에 노출되었 을 때, 오만성 프라이드에서 진정성 프라이드 보다 공감적 관 심성이 낮고, 공감적 관심성이 낮을수록 판단차이 값이 낮게 식별되어, 공감적 관심성의 매개역할이 입증되었다.

다섯째, 초기의 판단 이후에 타인의 불일치 정보에 노출되 었을 때, 프라이드유형의 판단차이 효과가 동기유형에 의해 조 절되어, 오만성 프라이드를 느낀 소비자의 방어 동기에서 판단 차이 값이 가장 작은 것으로 탐색되었다.

여섯째, 타인의 불일치 정보에 노출된 집단에서 동기유형의 판단차이효과에 대한 자기타당화의 매개역할이 없는 것으로 분석되었다.

동기유형의 판단차이효과에서 자기타당화의 매개역할을 분 석하였는데, 방어 동기에서 정확성 동기 보다 자기타당화의 수 준이 높은 것으로 나타났지만, 자기타당화가 판단차이에 영향 을 미치지 못하는 것으로 식별되고 자기타당화의 매개역할이 기각되었다. 이 연구에서 자신의 성과가 자질에 귀인되어 느끼 는 오만성 프라이드와 노력에 귀인되어 느끼는 진정성 프라이 드의 유형을 구분하여 접근하였는데, 자기타당화에서 자질적 자기타당화와 노력적 자기타당화를 개념적으로 구분하지 못하 였고, 기능적 차이를 탐색하지 못하였다. 소비자가 자질적 자 기타당화와 노력적 자기타당화를 모두 자기타당화로 볼 수도 있음을 간과하였다. 소비자가 자신만의 지능 또는 자질에서 자 기타당화를 할 수 있지만, 소비자는 성과에 노력을 귀인 하는 경우에 '나니까 그런 노력을 할 수 있다'는 자가타당화를 할 수도 있다. 따라서 자기타당화를 자질적 자기타당화와 노력적 자기타당화로 구분하여 접근할 필요가 있다.

\section{2. 연구의 시사점}

이 연구는, 기존의 선호도판단에 부정적으로 불일치하는 타 인의 정보에 소비자가 노출되었을 때에, 오만성 프라이드를 느 낀 소비자 보다 진정성 프라이드를 느낀 소비자의 최종 선호 도가 초기 선호도판단과 부정적으로 큰 차이를 나타내는 심리 
적 메카니즘을 연구하였다. 타인의 정보에 대한 공감적 관심도 의 매개역할, 프라이드의 유형별 불일치정보의 처리에서 선호 도판단차이에 대한 정확성 대비 방어 동기의 상호작용역할을 탐색하여, 프라이드의 유형별 자신의 선호판단에 대한 불일치 정보의 처리이론의 발전에 이 연구는 기여하고 있다.

그리고 마케터에게 관리적 시사점을 제안한다. 마케터가 경 쟁브랜드와 자사의 브랜드에 관한 속성 정보를 프라이드를 느 끼는 소비자에게 전달할 때, 소비자의 프라이드가 오만성 프라 이드인가 진정성 프라이드인가를 구분하여 접근해야 한다.

자사의 브랜드가 경쟁 브랜드 보다 못하다고 평가하는 소비 자 중에서 진정성 프라이드를 느끼는 소비자에게 정보처리에 서 정확성 동기를 갖도록 유도하고, 또 타인 소비자의 의견에 대한 공감적 관심성을 촉진하여, 자사의 브랜드가 경쟁브랜드 보다 우수하다고 평가하는 타인 소비자의 자사브랜드 속성정 보를 발굴하고 전달해야 한다. 그리고 자사의 브랜드가 경쟁 브랜드 보다 우수하다고 평가하는 소비자에게 방어 동기를 유 도하고 자사의 브랜드가 경쟁브랜드 보다 우수한 속성정보, 또 는 자사의 브랜드에 긍정적인 평가가 있는 소비자의 연상 네 트워크 스키마(schema)에 일치하는 정보를 전달해야 한다.

경쟁 브랜드보다 자사의 브랜드에 대한 선호도가 낮은 오만 성 프라이드를 느끼는 소비자에게 정확성 동기를 유도하고 타 인 소비자의 불일치 속성정보에 대한 공감적 관심도를 갖게 하는 방안을 탐색하고 실행해야 한다. 그리고 자사의 브랜드가 경쟁 브랜드보다 우수하다고 평가하는 경우에 방어 동기를 유 도하고 자사의 브랜드의 우수한 속성정보를 전달해야 한다.

\section{3. 연구의 한계와 미래 연구}

이 연구는 이론적 관리적 시사점과 함께 한계점과 미래의 연구분야를 제시한다.

첫째, 오만성 프라이드를 유발하는 자질과 진정성 프라이드 를 유발하는 노력에서, 자질과 관련된 제품 브랜드의 속성과 노력과 관련된 제품 브랜드의 속성을 이 연구는 구분하지 못 했다. 오만성 프라이드를 느끼면서 수행지향성에 초점을 두는 소비자에게 소구할 수 있는 속성정보와 진정성 프라이드를 느 끼면서 과업지향성에 초점을 두는 소비자에게 소구할 수 있는 속성정보의 유형을 식별하는 연구가 필요하다.

둘째, 과거에 경쟁브랜드를 선호도하면서 진정성 보다 오만 성 프라이드를 느끼는 소비자가 자신의 기존 선호도에 불일치 하는 타인 소비자의 정보에 대한 공감적 관심도와 정확성 동 기를 유발할 수 있는 방안을 탐색하는 연구가 필요하다.

셋째, 이 연구는 초기 판단과 최종 판단 간의 차이에 영향 을 미치는 프라이드의 유형에서 매개변인의 연구에 초점이 있 었다. 그런데 자아의 해석과 광고 메시지의 유형이 광고되는 브랜드의 선호도에 영향을 미칠 수 있다(Choi, Liu, \& Li, 2018). 경쟁브랜드를 선호하는 오만성 프라이드를 느끼는 소 비자에게 자질 보다 노력하는 자아에 관심을 유도하여 노력자 아의 효과에 관한 연구도 필요하다. 타인의 불일치 정보에도 경쟁브랜드를 선호하는 오만성 프라이드를 느끼는 소비자가 경우에, 노력하는 자아에 대한 존중감을 유발할 수 있는 방안 을 탐색하고 기존 선호도에 의구심이 촉진될 수 있는 정보메 시지의 유형에 관한 연구가 필요하다.

넷째, 개인주의 문화에서 소비자는 타인과의 일체감에서 탈 피하여 개인적 파워에 더 의미를 부여할 수 있고, 집단주의 문 화에서 소비자는 타인과의 관계를 구축하기 위하여 사회적 관
계에서 소속감에 더 의미를 부여할 수 있다(Choi \& Dhakal, 2017; Lee \& Wang, 2018). 따라서 공감적 관심성이 개인주의 문화보다 집단주의 문화에서 타인의 불일치 정보에 따른 최종 판단에 더 큰 영향을 미칠 수 있다. 따라서 문화의 차이에 따 른 공감적 관심성의 역할을 더욱 연구할 필요가 있다.

\section{Reference}

Agrawal, N., Han, D., \& Duhachek, A. (2013). Emotional agency appraisals influence responses to preference inconsistent information. Organizational Behavior and Human Decision Processes, 120(1), 87-97.

Ashton-James, C. E., \& Tracy, J. L. (2012). Pride and prejudice: How feelings about the self influencejJudgments of others. Personality and Social Psychology Bulletin, 38(4), 446-476.

Beer, J. S., \& Keltner, D. (2004). What is unique about self-conscious emotions?. Psychological Inquiry, 15(2), 126-129.

Biondo, J., \& MacDonald, A. P. (1971). Internal-external locus of control and response to influence attempts. Journal of Personality, 39(3), 406-419.

Brehm, J. W. (1966), A Theory of Psychological Reactance. New York, NY: Academic Press.

Carlson, K. A., \& Russo, J. E. (2001). Jurors' distortion of evidence in legal trials. Journal of Experimental Psychology: Applied, 7(2), 91-103.

Carlson, K. A., Tanner, R. J., Meloy, M. G., \& Russo, J. E. (2014). Catching nonconscious goals in the act of decision making. Organizational Behavior and Human Decision Processes, 123(1), 65-76.

Chaiken, S., \& Eagly, A. H. (1989). Heuristic and systematic information processing within and beyond the persuasion context. In James, S. U. John \& A. Bargh(eds.), Unintended Thought(PP. 212-252). New York, NY: Guilford Press.

Chaxel, A.-S. (2016). Why, when, and how personal control impacts information processing: A framework. Journal of Consumer Research, 43(1), 179-197.

Choi, N.-H., \& Dhakal, A. (2017). Roles of power state and message types on restaurant store brand attitude. Journal of Distribution Science, 15(10), 5-14.

Choi, N.-H., Liu, H., \& Li, Z. (2018). The effects of Chinese consumers' self-construal and advertising type on brand attitude. East Asian Journal of Business Management, 8(3), 33-41.

Cosmides, L., \& Tooby, J. (2000). Evolutionary psychology and the emotions. In M. Lewis \& J. M. Haviland-Jones, Handbook of Emotions, 2nd ed.(PP. 91-115), New York, NY: Guilford.

Crocker, J., \& Park, L. E. (2004). The costly pursuit of self-esteem. Psychological Bulletin, 130(3), 392-414.

Cutright, K. M. (2011). The beauty of boundaries: When 
and why we seek structure in consumption. Journal of Consumer Research, 38(5), 775-790.

Cutright, K. M., Bettman, J. R., \& Fitzsimons, G. J. (2013). Putting brands in their place: How a lack of control keeps brands contained. Journal of Marketing Research, 50(3), 365-377.

DeKay, M. L., Stone, E. R., \& Miller, S. A. (2011). Leader-driven distortion of probability and payoff information affects choices between risky prospects. Journal of Behavioral Decision Making, 2(4), 394-411.

DeKay, M. L., Stone, E. R., \& Sorenson, C. M. (2012). Sizing up information distortion: Quantifying its effect on the subjective values of choice options. Psychonomic Bulletin and Review, 19(2), 349-356.

Dovidio, J. F., Johnson, J. D., Gaertner, S. L., Pearson, A. R., Saguy, T., \& Ashburn-Nardo, L. (2010). Empathy and intergroup relations. In M. Mikulincer \& P. Shaver (eds.), Prosocial Motives, Emotion, and Behavior: The Better Angels of Our Nature(PP. 393-408). Washington, DC: APA Press.

Dweck, C. S. (2006). Mindset: The New Psychology of Success. New York, NY: Random House.

Eisenberg, N., \& Strayer, J. (1987). Critical Issues in the study of empathy. In N. Eisenberg \& J. Strayer(eds.), Empathy and Its Development(PP. 3-16). Cambridge, UK: Cambridge University Press.

Escalas, J. E., \& Stern, B. B. (2003). Sympathy and empathy: Emotional responses to advertising dramas. Journal of Consumer Research, 29(4), 566-578.

Finlay, K. A., \& Stephan, W. G. (2000). Reducing prejudice: The effects of empathy on intergroup attitudes. Journal of Applied Social Psychology, 30(8), 1720-1737.

Fischer, P., Kastenmuller, A., Greitemeyer, T., Fischer, J., Frey, D., \& Crelley, D. (2011). Threat and selective exposure: The moderating role of threat and decision context on confirmatory information search after decisions. Journal of Experimental Psychology, General, 140(1), 51-62.

French, D. P., Hevey, D., Sutton, S., Kinmonth, A. L., \& Marteau, T. M. (2006). Personal and social comparison information about health risk: Reaction to information and information search. Journal of Health Psychology, 11(3), 497-510.

Galinsky, A. D., \& Ku, G. (2004). The effects of perspective-taking on prejudice: The moderating role of self-evaluation. Personality and Social Psychology Bulletin, 30(5), 594-604.

Giner-Sorolla, R. (2001). Guilty pleasures and grim necessities: Affective attitudes in dilemmas of self-control. Journal of personality and social psychology, 80(2), 206.

Glaser, J., Dixit, J., \& Green, D. P. (2002). Studying hate crime with the internet: What makes racists advocate racial violence. Journal of Social Issues, 58(1),
177-193.

Hart, J. (2014). Toward an integrative theory of psychological defense. Perspectives on Psychological Science, 9(1), 19-39.

Hart, W., Albarracin, D., Eagly, A. H., Brechan, I., Lindberg, M. J., \& Merrill, L. (2009). Feeling validated versus being correct: A meta-analysis of selective exposure to liformation. Psychological Bulletin, 135(4), 555-88.

Hayes, A. F. (2013). Introduction to Mediation, Moderation, and Conditional Process Analysis, New York, NY: Guilford.

Jain, S. P. (2003). Preference consistency and preference strength: Processing and judgmental issues. Journal of Applied Social Psychology, 33(5), 1088-1109.

Jain, S. P., \& Maheswaran, D. (2000). Motivated reasoning: A depth-of-processing perspective. Journal of Consumer Research, 26(4), 358-371.

Joireman, J. A., Parrott, L., \& Hammersla, J. (2002). Empathy and the self-absorption paradox: Support for the distinction between self-rumination and self-reflection. Self and Identity, 1(1), 53-65.

Jonas, E., \& Frey, D. (2003). Information search and presentation in advisor-client interactions. Organizational Behavior and Human Decision Processes. 91(2), 154-168.

Kay, A. C., Whitson, J. A., Gaucher, D., \& Galinsky, A. D. (2009). Compensatory control: Achieving order through the mind, our institutions, and the heavens. Current Directions in Psychological Science, 18(5), 264-268.

Kenrick, D. T., \& Shiota, M. N. (2008). Approach and avoidance motivation(s): An evolutionary perspective. In A. J. Elliot(ed.), Handbook of Approach and Avoidance Motivation(PP. 271-285). New York, NY: Psychology Press.

Lee, J. W., \& Wang, Z. (2018). Spillover effects of foreign direct investment inflows and exchange rates on the banking industry in China. Journal of Asian Finance, Economics and Business, 5(2), 15-24.

Lerner, J. S., \& Keltner, D. (2000). Beyond Valence: Toward a model of emotion-specific influences on judgment and choice. Cognition and Emotion, 14(4), 473-493.

Lerner, J. S., Han, S., \& Keltner, D. (2007). Feelings and consumer decision making: Extending the appraisal-tendency framework. Journal of Consumer Psychology, 17(3), 158-168.

Lewis, M. (2016). Self-conscious emotions: Embarrassment, pride, shame, guilt, and hubris. Handbook of emotions, 4, 792-814.

Louro, M. J., Pieters, R., \& Zeelenberg, M. (2005). Negative returns on positive emotions: The influence of pride and self-regulatory goals on repurchase decisions. Journal of Consumer Research, 31(4), 833-840. 
Maclnnis, D. J., \& Patrick, V. M. (2006). Spotlight on affect: Affect and affective forecasting in impulse control. Journal of Consumer Psychology, 16(3), 224-231.

McGuire, W. J. (1989). The structure of individual attitudes and attitude systems. In A. R. Pratkanis, S. J. Breckler \& A. G. Greenwald(eds.), Attitude Structure and Function(PP. 37-69). Hillsdale, NJ: Erlbaum.

Meloy, M. G., \& Russo, J. E. (2004). Binary choice under instructions to select versus reject. Organizational Behavior and Human Decision Processes, 93(2), 114-128.

Niedernhuber, J., Kastenmueller, A., \& Fischer, P. (2014). Chaos and decision making: Contextual disorder reduces confirmatory information processing. Basic and Applied Social Psychology, 36(3), 199-208.

Passyn, K., \& Sujan, M. (2012). Skill-based versus effort-based task difficulty: A task-analysis approach to the role of specific emotions in motivating difficult actions. Journal of Consumer Psychology, 22(3), 461-468.

Pettigrew, T. F., \& Tropp, L. R. (2008). How does intergroup contact reduce prejudice? Meta-analytic tests of three mediators. European Journal of Social Psychology, 38(6), 922-934.

Petty, R. E., Briñol, P., \& Tormala, Z. L. (2002). Thought confidence as a determinant of persuasion: The self-validation hypothesis. Journal of personality and social psychology, 82(5), 722-741.

Rogers, T. B., Kuiper, N. A., \& Kirker, W. S. (1977). Self-reference and the encoding of personal information. Journal of personality and social psychology, 35(9), 677-688.

Rotter, J. B. (1966). Generalized expectancies for internal versus external control of reinforcement. Psychological
Monographs, 80(1), 1-28.

Russo, E. J. (2015). The predecisional distortion of information. In E. A. Wilhelms \& V. F. Reyna(eds.), Neuroeconomics, Judgment, and Decision Making(PP. 91-110). New York, NY: Psychology Press.

Strayer, J. (1987). Affective and cognitive perspective on empathy. In N. Eisenbreg \& J. Strayer(eds.), Empathy and its Development(PP. 218-244). Cambridge, UK: Cambridge University Press.

Tracy, J. L., \& Robins, R. W. (2004). Putting the self into self-conscious emotions: A theoretical model. Psychological Inquiry, 15(2), 103-125.

Tracy, J. L., \& Robins, R. W. (2007). The psychological structure of pride: A tale of two facets. Journal of Personality and Social Psychology, 92(3), 506-525.

Tracy, J., L., \& Robins, R. W. (2014). Conceptual and empirical strengths of the authentic/hubristic model of pride. Emotion, 14(1), 33-37.

Weiss, L., \& Johar, G. V. (2013). Egocentric categorization and product judgment: Seeing your traits in what you own (and their opposite in what you don't). Journal of Consumer Research, 40(1), 185-201.

Wilcox, K., Kramer, T., \& Sen, S. (2010). Indulgence or self-control: A dual process model of the effect of incidental pride on indulgent choice. Journal of Consumer Research, 38(1), 151-163.

Wispé, L. (1986). The distinction between sympathy and empathy : To call Forth a concept, a word is needed. Journal of Personality and Social Psychology, 50(2), 314-321.

Zhang, H., Chan, D. K. S., \& Guan, Y. (2013). Plans are more helpful when one perseveres: The moderating role of persistence in the relationship between implementation intentions and goal progress. Basic and applied social psychology, 35(2), 231-240. 